\title{
A 2014-es jégtörés tulajdonságai és az azt követő erdészeti fakitermelés hatásai a Börzsöny erdeiben
}

\author{
Zoltán László és Standovár Tibor \\ Eötvös Loránd Tudományegyetem, Növényrendszertani, Ökológiai és Elméleti Biológiai \\ Tanszék, 1117 Budapest, Pázmány Péter sétány 1/C \\ e-mail: zoltan.laci93@gmail.com
}

\begin{abstract}
Összefoglaló: Munkánk során a 2014-ben bekövetkezett - az elmúlt 50 év legnagyobb kiterjedésű és intenzitású - jégtörésének hatásait vizsgáltuk a Börzsönyben. Elvégeztük a jégtörés egyes tulajdonságainak kvantitatív leírását és összehasonlítottuk a korábbi börzsönyi jégtörésekkel kapcsolatos kutatások eredményeivel.A jégtörés előtt felmért területek újrafelvételezésével (azonos módszertan alapján) lehetőség nyílt a jégtörés hatásainak kimutatására. A 885 db mintavételi pont elemzése alapján megállapítható, hogy a jégtörés a nitrofil lágyszárúak tömeges felszaporodását, illetve az alacsony $(<50 \mathrm{~cm})$ újulat borításának növekedését váltotta ki. E változások mértékét befolyásolhatja, hogy megtörtént-e a kidőlt faanyag összetermelése, s ha igen milyen technikával. Az erdészeti gépek által okozott talajbolygatás jobban károsítja az újulatot és nagyobb nitrofil borítást eredményez, mint a tradicionális közelítési technikák (lovas, kézi). Az erdőgazdálkodás alól több évtizede kivont Pogány-Rózsás Erdőrezervátum területén az erdők a gazdaságiakhoz képest kevésbé károsodtak.
\end{abstract}

Kulcsszavak: bolygatásjelző lágyszárúak, erdőrezervátum, Fagus sylvatica, jégkár, közelítés, nitrofil lágyszárúak, természetes bolygatás, természetközeli erdőgazdálkodás

\section{Bevezetés}

Az elmúlt 40-50 év során Európa erdeit egyre nagyobb intenzitású természetes bolygatások érték, sokszor jelentős gazdasági károkat okozva (Schelhaas et al. 2003). A legelterjedtebb vágásos erdőgazdálkodás elegyfajokban szegény, egykorú, homogén szerkezetü faállományokat alakít ki. Az ilyen állományok gyengébb ellenálló képességgel rendelkeznek természetes bolygatásokkal szemben (Irland 2000, Aszalós et al. 2001). A természetes bolygatások (pl. széldöntés, jégtörés) természetvédelmi szempontból kedvezőek, hiszen szerves részei az erdőciklusnak és a keletkező holtfa számtalan élölénynek biztosít életteret, ezzel növelve a biodiverzitást.

A Börzsönyben 1996-ban, 2001-ben, 2004-ben és 2014-ben történt jégtörés (Zoltán 2018). A 2014-es jégtörés döntően erdőgazdálkodás alatt álló területeket 
érintett, ezért a holt faanyag egészségügyi kitermelése nagyrészt már megtörtént. A gazdálkodás alól már több évtizede kivont Pogány-Rózsás Erdőrezervátum területén csak az utak felszabadítása történt meg, így az többé-kevésbé antropogén bolygatás mentes, természetközeli állománynak tekinthetö.

A holt faanyag kitermelésére különböző közelítési technikákat alkalmaznak, amelyek eltérően hatnak a nitrofil lágyszárúak és az újulat borítására (Fidej et al. 2016). Mivel ilyen nagymértékü bolygatásról még nincsenek magyarországi adataink, célszerűnek láttuk a jégtörés (1) kvantitatív jellemzését és összehasonlítását korábbi bolygatásokkal, (2) közvetlen hatásait vizsgálni a faállományra és az aljnövényzetre, (3) a jégtörés utáni kitermelés hatásait és ezeknek az erdő felújulására gyakorolt hatásait elemezni.

\section{Módszerek}

A kvantitatív jellemzéshez korábbi regionális irodalmi adatokkal végeztünk öszszehasonlítást. Lékméret eloszlásokat készítettünk különböző dőlési kategóriák (egy folton belül a faállomány mekkora hányada dőlt ki) szerint, 2015-ben készült légifelvételeken alapuló, a teljes Börzsönyt lefedő bolygatási térkép (Tanács et al. 2017) alapján.

Az adatgyüjtés az „Erdei életközösségek védelmét megalapozó többcélú állapotértékelés a magyar Kárpátokban" - SH-4/13 projekt keretein belül zajlott, annak a protokollját követte (Standovár et al. 2016): 70×70 méteres háló rácspontjaiban kihelyezett $500 \mathrm{~m}^{2}$-es mintakörökben információt gyüjtöttünk többek között a bolygatásokról, záródásról, faállományról, (alacsony) újulatról $(<50 \mathrm{~cm})$, lágyszárúakról stb. Az erdóállapot felmérések 2014-ben, a jégtörés előtt megkezdődtek, így a jégtöréssel érintett területek egy részének újrafelvételezése lehetővé tette a jégtörés hatásainak elemzését. A munkánk során $885 \mathrm{db}$ mintavételi pontot vettünk fel az Ipolyerdő Zrt. Diósjenői és Kemencei Erdészeteinek területén a 2015-2017 évek nyári időszakai során (részletek: Zoltán 2018). Mintavételi területeink közé tartozott a Pogány-Rózsás Erdőrezervátum egy része is.

A jégtörés közvetlen hatásait a faállományra és az aljnövényzetre párosított Wilcoxon-féle nem-paraméteres tesztekkel vizsgáltuk. A közelítési hatásvizsgálathoz kiválasztott $\mathrm{N}=358$ pont kijelölésekor elsődleges szempont volt a $<25 \%$-os dőlés (a kismértékủ dőlés melletti markáns reakció kimutatása céljából, Tanács et al. 2017 alapján), és a bükk (Fagus sylvatica) dominancia. Azokon a területeken, ahol az újrafelvételezés időpontjáig megtörtént az egészségügyi termelés, összehasonlítottuk a különbözö kitermelési módszerek $\left(\mathrm{N}_{\text {gépi }}=46, \mathrm{~N}_{\text {kézi }}=34, \mathrm{~N}_{\text {lovas }}=\right.$ 39; referenciaként pedig $\mathrm{N}_{\text {nem_kitermelt_gazdasági_erdỏ }}=149, \mathrm{~N}_{\text {Pogány-Rózzás__Erdörezervátum }}=90$ ) 
hatásait az újulatra és lágyszárúakra Kruskal-Wallis-próbákkal, majd Dunn-féle post-hoc tesztekkel.

Vizsgálatainkhoz QGIS 2.16.0. szoftvert használtunk, a statisztikai vizsgálatokat R 3.2.2. programmal végeztük el.

\section{Eredmények}

Az 1. táblázat az 1996-os és 2001-es jégtörés jellemzöit hasonlítja a 2014-ben megfigyeltekhez. A 2014-es jégtörés topográfiai és az állományokra jellemző tulajdonságait is figyelembe véve sokkal nagyobb tartományt fedett le, mint a korábbi bolygatások.

A különböző mértékben dőlt foltok méreteloszlását bemutató 1. ábrán látható, hogy a dőlési kategóriák jelentős része a 0,1 hektárnál nagyobb területekről írhatók le.

1. táblázat: Börzsönyi jégtörések legfontosabb kvantitatív jellemzői. A 2004-es jégtörést nem vizsgálták. Az érintett területek topográfiai és állományt leíró adatainak forrásai: 1996: Aszalós et al. 2001; 2001: Aszalós et al. 2004; 2014: Zoltán 2018. A hektárokra vonatkozó kárbecslések (sporadikus károk is bevonva) forrásai: 1996 és 2001: Kenderes 2008; 2014: Hirka 2015. A m³-re vonatkozó kárbecslések forrásai: 1996: Aszalós et al. 2012; 2001: Tóth Gábor, szóbeli közlés, 2004; 2014: Kiss László, szóbeli közlés, 2017. Az érintett erdészetekre vonatkozó források: 1996, 2001: Standovár et al. 2006.

\begin{tabular}{lccc}
\hline & \multicolumn{3}{c}{ Börzsönyi jégtörések } \\
Év & 1996 & 2001 & 2014 \\
\hline Kitettség & ÉK-K-DK-D & ÉK-K-DK-D & ÉK-K-(DK-D)-DNY-NY \\
Meredekség $\left({ }^{\circ}\right)$ & $17<$ & $18<$ & $15<$ \\
Magasság $(\mathrm{m})$ & $438-800$ & $500-700$ & $310-820$ \\
Bükk elegyarány (\%) & $43<$ & $42<$ & $0-100$ (átlag: 66) \\
Állomány kora (év) & $54<$ & $50-100$ & $40-125$ \\
Károsodott terület $($ ha) & 942 & 1561 & 3630 \\
Károsodott faanyag $\left(1000 \mathrm{~m}^{3}\right)$ & 35 & 65 & 200 (150 kitermelve) \\
& & Diósjenői & Diósjenői \\
Jelentősen érintett erdészetek & Királyréti & Kemencei & Kemencei \\
& & &
\end{tabular}

A jégtörés közvetlen, elsődleges hatásai között szerepel a nitrofil lágyszárúak jelentős mértékü térnyerése ( $\mathrm{W}=91460 \mathrm{~N}=885 \mathrm{p}<0,001$ ). Faji szinten a nagy csalán (Urtica dioica), a göcsös görvélyfü (Scrophularia nodosa) és a maszlagos nadragulya (Atropa bella-donna) jelent meg legnagyobb tömegességben. Az ökörfarkkóró fajok (Verbascum spp.) a nagy kiterjedésü dőlésekhez kötőd- 


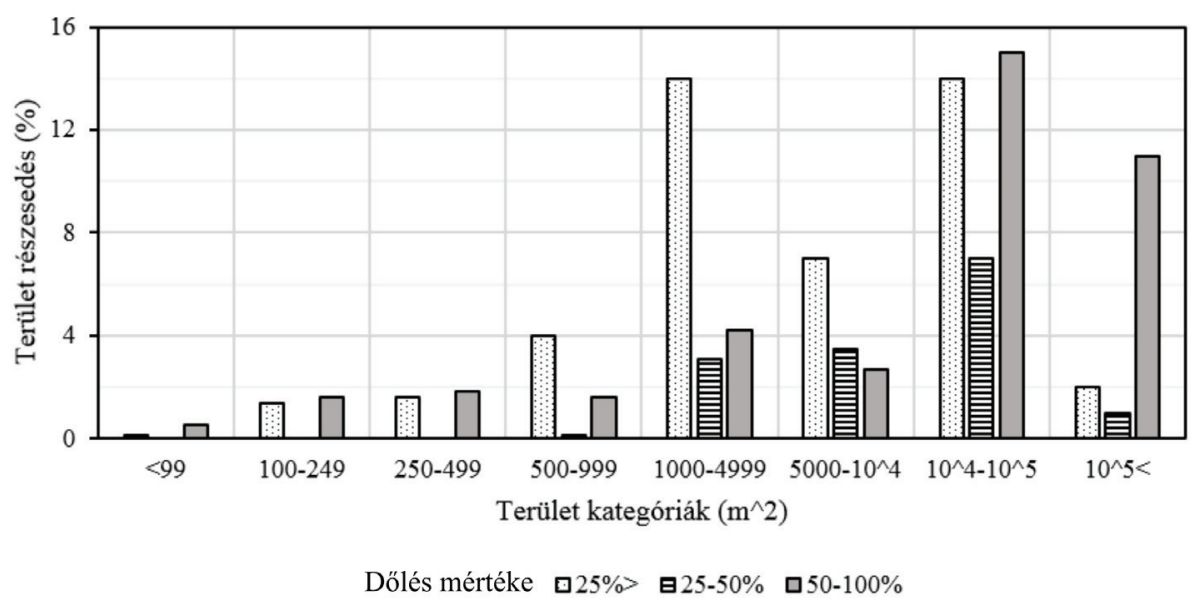

1. ábra: A 2014-es jégtörés során keletkezett, különböző mértékben dőlt foltok méreteloszlása a manuálisan lehatárolt légifelvétel-alapú poligonok alapján. Az elemzésben csak a dőlt területeket vizsgáltuk (vagyis a csak lombkoronakárosodott területeket nem tartalmazza). Az összes dőlési-kategória együttesen adja ki a 100\%-ot.

nek és szokatlanul nagy a tömegességük ezeken a területeken. A siska nádtippan (Calamagrostis epigeios) kizárólagosan a jégtörést követően kitermelt területekhez kötődik.

Az alacsony újulat borításáért a bükk, a gyertyán (Carpinus betulus) és a magas köris (Fraxinus excelsior) fajok borításának növekedése (W=220230 N=885 $\mathrm{p}<0,001)$ felelős.

A fő faállományalkotó fafajok elegyarányának változásaiért a bükk és a gyertyán felelős (részletek: Zoltán \& Standovár 2017), a bükk károsodott a legnagyobb mértékben.

A jégtörést követő kitermelés hatásainak összehasonlítása során a nitrofil lágyszárúak $\left(\chi^{2}=28,17 \mathrm{p}<0,001\right)$ és az alacsony újulat borítása változott $\left(\chi^{2}=16,13\right.$ $\mathrm{p}<0,001)$ szignifikánsan a Kruskal-Wallis tesztek alapján.

A nitrofil lágyszárúak borítása legnagyobb mértékben a gépi közelítés hatására nőtt meg (2/a ábra). Az erdőrezervátum esetében alig nőtt ez az érték, különbözött a kitermelt területektől, de a nem kitermelt gazdasági erdőktől nem. Minden gazdasági mủvelés alatt álló erdőben az újulat pusztulása figyelhető meg, míg az erdőrezervátumi területeken maximum csak stagnált az alacsony újulat borítása (2/b ábra).

A 3/a ábrán látható a nitrofil lágyszárúak és az alacsony újulat borítás-változása közötti összefüggés. A 3/b ábra a jégtörés utáni borítási kategóriák gyakoriságeloszlásait mutatja.

A 3/a ábra eredményei ugyan egyik esetben sem mutatnak szignifikáns különbséget, mégis érdemes megvizsgálni őket. A nitrofil lágyszárú borítás növekedése 


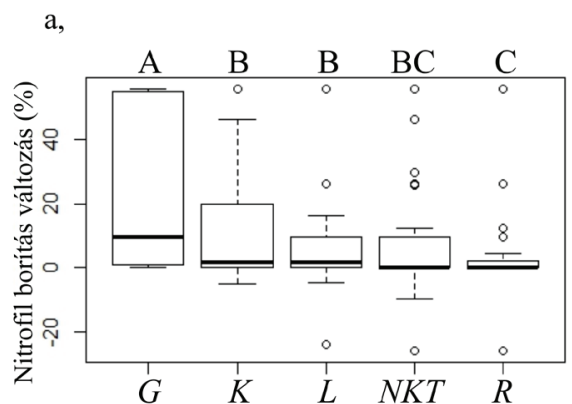

Közelítés típusa

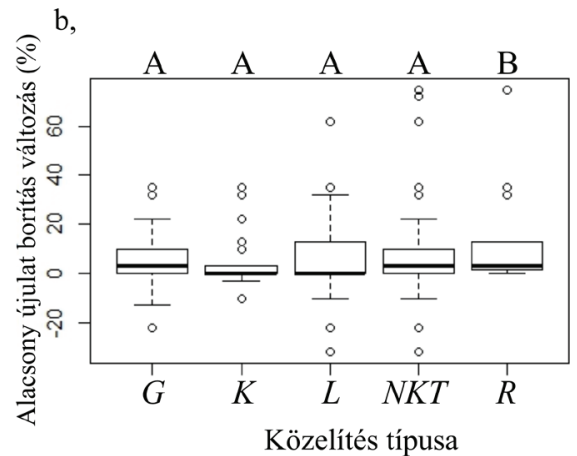

Közelítés típusa

2. ábra: Nitrofil lágyszárúak és az alacsony újulat borításának jégtörésre adott válaszreakciója különböző összetermelési technikák esetében. Jelmagyarázat: $\square:$ IQR (interkvartilis terjedelem); —: medián; $\top^{\perp}$ : $\mathrm{x}>\mathrm{Q} 3+1,5$ IQR és $\mathrm{x}<\mathrm{Q} 1+1,5 \mathrm{IQR}$ (Q1: alsó kvartilis; Q3: felső kvartilis); ○: kiugró értékek; G: gépi, L: lovas, K: kézi, NKT: nem kitermelt gazdasági erdő, R: Pogány-Rózsás Erdőrezervátum. Az a, ábrán a Dunn post-hoc teszt szerint a nitrofil lágyszárúak borítás-változása a gépi kitermelés esetében különbözött mindegyik másik kategóriától ( $\mathrm{L}$ : d=2,59 p<0,01; K: $\mathrm{d}=2,41 \mathrm{p}<0,01$; NKT: $\mathrm{d}=4,62 \mathrm{p}<0,001, \mathrm{R}: \mathrm{d}=4,81 \mathrm{p}<0,001)$, illetve az erdőrezervátumi minták különböztek szignifikánsan a többitől (K: $\mathrm{d}=1,85 \mathrm{p}=0,03$; $\mathrm{L}$ : $\mathrm{d}=1,86 \mathrm{p}=0,03)$, kivéve a NKT-tól $(\mathrm{d}=1,07 \mathrm{p}=0,14)$. A $\mathrm{b}$, ábrán a Dunn post-hoc teszt szerint az alacsony újulat borítás-változása az erdörezervátumi minták esetében különbözött szignifikánsan az összes többitől ( $G$ : d=-2,64 $\mathrm{p}<0,01 ; \mathrm{L}: \mathrm{d}=-3,41 \mathrm{p}<0,001 ; \mathrm{K}: \mathrm{d}=-2,34 \mathrm{p}<0,01, \mathrm{NKT}: \mathrm{d}=-3,39 \mathrm{p}<0,001)$.

$\mathrm{a}$,

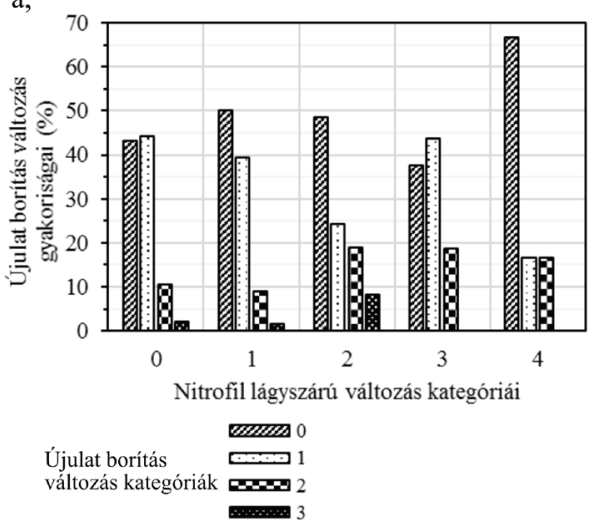

$\mathrm{b}$,

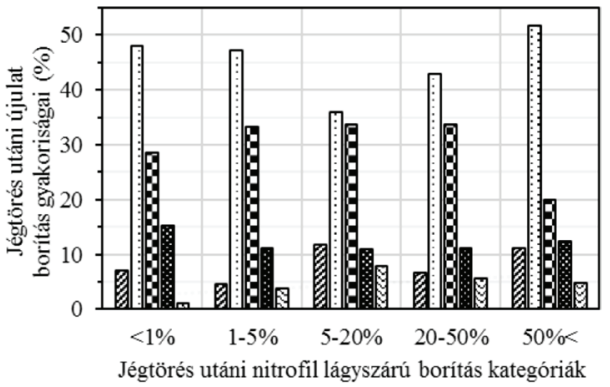

Újulat borítás
kategóriák

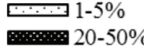

3. ábra: A nitrofil lágyszárúak, és az alacsony újulat $(<50 \mathrm{~cm})$ borítása közti összefüggés. Az a, ábrán az x-tengely kategóriái azt mutatják meg, hogy hány darab kategóriát változott az ordinális skálán értelmezett borítási érték a jégtörés előtt és után (szövegesen: 0-nál nem történt borítás változás, 1-3 között növekedett, 4-nél pedig tömegessé vált). A különböző mintázatú oszlopok pedig ugyan ezt jelentik az újulat esetében. Az y-tengely pedig azt mutatja meg, hogy hogyan változott az újulat borítás gyakorisága a nitrofil lágyszárú borítás változásának függvényében. $\mathrm{A} b$, ábrán az x-tengelyen a nitrofil lágyszárú-borítás kategóriák láthatók, az oszlopok esetében pedig újulat borítás kategóriák. Az y-tengelyen az látható, hogy milyen gyakorisággal fordult elő az adott tömegességü alacsony újulat, bizonyos mértékü nitrofil lágyszárú tömegesség mellett a jégtörést követöen. 
mellett egyre nagyobb valószínüséggel nem növekedett az alacsony újulat borítása (3/a ábra, 0 érték). Ugyanitt észre lehet venni azt is, hogy a (3)-as újulat növekedési kategória a magasabb nitrofil lágyszárú növekedési kategóriáknál (3-4) már nem jelenik meg. A 3/b ábrán a $(50 \%<)$-os nitrofil lágyszárú borítási kategória esetében látható, hogy az (1-5\%)-os újulat borítás kategória az uralkodó, amely az újulat kismértékủ jelenlétére utal a többi kategóriához képest.

\section{Értékelés}

Az 1. táblázatból látható, hogy a korábbi évek publikált eredményei eltérnek a 2014-es természetes bolygatásétól, kiváltképp az égtáji kitettség jellemzői. A 2014-es jégtörés volt a legintenzívebb és legnagyobb területet érintő.

A jégtörést a nagy területü lékek jellemzik leginkább. Intenzív bolygatások hiányában 10-1000 $\mathrm{m}^{2}$ között várunk haranggörbe-szerü összefüggést kb. 200-500 $\mathrm{m}^{2}$-es lék gyakorisági csúccsal (Kenderes 2008). Az 50-100\%-os kategória esetében látható, hogy ez esetben növekvő trendet mutat az eloszlás. Az 1996-os jégtörés során 1-10 hektáros lékek keletkeztek (Aszalós et al. 2012), amelyek kisebb területüek, mint a 2014-es során tapasztaltak, hiszen a legnagyobb „lék” több, mint 88 ha területü és totális dőlést szenvedett el (Rakottyás-völgy). Ekkora mértékü dőlésnek már tájléptékü átalakító hatása lehet és természetes körülmények között csak nagyon ritkán fordul elő (lavina, tornádó stb.). A többi dőlési kategória is inkább tájléptékben jelentkezett, nagy, egybefüggő dőlési mintázat szerint.

A nitrofil lágyszárúak és az újulat borítása a jégtörés hatására megváltozott, de a kitermeléskor alkalmazott technológia nagyban befolyásolja e változások irányát, mértékét (2. ábra). A gépi közelítéssel kitermelt állományok esetében a legnagyobb mértékủ a nitrofil lágyszárúak borítás-növekedése, amelyet az ismételt nagy területet érintő talajbolygatás okozhat. Az egészségügyi termelés során használt gépi közelítés relatíve nagyobb talajbolygatást okozhat, mintha más fahasználati technológiát alkalmaznának, hiszen fekvő holtfákat kerülgetnek a gépek mozgása közben.

A lovas közelítés is jobbnak tünik a gépinél. A lovas közelítés tradicionális, természetközeli kitermelési mód, amely kisebb környezetterhelést jelent, mint a gépek használata (Lihai 1996).

Ugyan a kézi kitermelésủ területek egy esetben sem különböztek szignifikánsan a többi kitermelési technikától, a box-plotokat megtekintve (2/a ábra) látható, hogy a nitrofil lágyszárúak borítás-változása hasonlít a nem kitermelt gazdasági erdőkhöz és valamelyest különbözik a lovas és gépi kitermelésü területektől. Az alacsony újulat esetében ( $2 / b$ ábra) megfigyelhető (ugyan kisebb mértékben, mint 
a többi kitermelési technológia esetében) az újulat pusztulása is. A kézi közelítés során a faanyag vágásterületen belül történő mozgatásához nem használnak semmilyen gépesített segédeszközt. A faanyagot kézben lehordják, dobják, gurítják csak emberi erőt alkalmazva. Ennek eredményeképp kisebb mértékü a talajsebzés, mint a lovas és gépi vonszolásos technikák alkalmazása során. A kézi kitermelési technológia kíméletességét támasztják alá az eredményeink is.

A kitermelt területeken megjelenő siskanád erdőfelújulást gátló hatása miatt további - potenciálisan később jelentkező - problémákra hívja fel a figyelmet.

A Pogány-Rózsás Erdőrezervátum sok esetben másképp reagált: dőlés helyett inkább koronatörés volt jellemző (Zoltán 2018), valamint jelentősen kisebb mértékủ a nitrofil lágyszárúak borítás-növekedése. Valószínüleg azért nem markánsabb a különbség, mert nem telt el kellően hosszú idő a gazdálkodás felhagyása óta, így annak hatásai még érvényesülnek. Az alacsony újulat borítása az erdőgazdálkodás alatt álló állományokban minden esetben csökkenést is mutat (az erdőrezervátumban nem változott vagy növekedett), ami felhívja a figyelmet a közelítési technikák újulatot károsító hatására.

Kapcsolat sejthető a nitrofil lágyszárúak és az alacsony újulat borításának változása (növekedése) között a jégtörés után (3. ábra). Minél tömegesebb a nitrofil lágyszárúak térnyerése, annál kisebb teret adhatnak az újulatnak, amely nem tud olyan gyorsan, akkora eréllyel növekedni (3/a ábra). A jégtörés utáni viszonyokat tekintve (3/b ábra) pedig látható, hogy a tömeges nitrofil lágyszárú jelenlét mellett a többihez mérten alacsonyabb borítással rendelkezik az újulat. Az is lehetséges, hogy mindez csak egy közvetett hatás az egészségügyi termelésen keresztül. E kapcsolat robusztusságának kimutatása több vizsgálatot igényelne.

A kutatásunk eredményei egy, a természeteshez közelebbi gazdálkodási módszer kialakításának szükségességét támasztják alá. Ajánljuk a kevésbé intenzív talajbolygatással járó közelítést, a bolygatásoknak jobban ellenálló heterogén faállomány összetételt, szerkezetet és a holtfák nagyobb mértékủ visszahagyását erdőgazdálkodással érintett területeken is. Védett természeti terület esetében nagyobb területen is indokolt lehet az összetermelés elhagyása, a spontán regeneráció biztosítása.

A klímaváltozás során egyre növekvő intenzitással és gyakorisággal jelentkeznek természetes bolygatások, amelyek a homogén állományokat kialakító erdészeti kezelésekkel kombinálódva a 2014-es jégtöréshez hasonló mértékủ gazdasági károkat is eredményezhetnek. E károk mérséklése érdekében, valamint a klímaváltozáshoz történő alkalmazkodást is segítendő javasolható az elegyetlen, homogén szerkezetü bükkösök elegyfajokban gazdagabb állományokká történő alakítása (Kelemen et al. 2013). 
Köszönetnyilvánítás - Kutatásunkat az SH-4/13 projekt finanszírozta. Köszönettel tartozunk az Ipolyerdő Zrt. erdészeinek: Szeles Gábornak, Szekán Györgynek, Zanati Lászlónak, Zagyvai Bencének. Terepi adatgyüjtésünket legnagyobb mértékben Vörös Dániel segítette.

\section{Irodalomjegyzék}

Aszalós, R., Standovár, T., Ruff, J. \& Barton, Zs. (2001): Jégtörések és széldöntések a Börzsöny erdeiben. - In: Mátyás, Cs., Führer, E. \& Tóth, J. (szerk.): Gondolatok az erdővédelemről az ezredfordulón. Az MTA Erdészeti Bizottsága és az Erdészet Tudományos Intézet jubileumi ülése Pagony Hubert és Szontagh Pál 75. születésnapja alkalmából. ERTI, pp. 103-116.

Aszalós, R., Standovár, T. \& Barton, Zs. (2004): A börzsönyi jégtörések okairól az országosan egyre nagyobb területet érintő jégtörések fényében. - In: Mátyás, Cs. \& Vígh, P. (szerk.): Erdő és Klíma IV. NyME, pp. 249-262.

Aszalós, R., Imelda, S., Kenderes, K., Ruff, J., Czúcz, B. \& Standovár, T. (2012): Accurate prediction of ice disturbance in European deciduous forests with generalized linear models: a comparison of field-based and airborne-based approaches. - Eur. J. Forest Res. 131: 1905-1915. doi: https://doi.org/10.1007/s10342-012-0641-6

Fidej, G., Rozman, A., Nagel, T. A., Dakskobler, I. \& Diaci, J. (2016): Influence of salvage logging on forest recovery following intermediate severity canopy disturbances in mixed beech dominated forests of Slovenia. - iForest. 9: 430-436. doi: https://doi.org/10.3832/ifor1616-008

Hirka, A. (ed) (2014): Országos erdőkár nyilvántartási rendszer. A 2014. évi biotikus és abiotikus erdőgazdasági károk, valamint 2015-ben várható kárositások. - NAIK Erdészeti Tudományos Intézet, NÉBIH Erdészeti Igazgatóság, 225 p.

Irland, L. C. (2000): Ice storms and forest impacts. - Sci. Total Environ. 262: 231-242. doi: https:// doi.org/10.1016/S0048-9697(00)00525-8

Kelemen, K., Mag, Zs., Aszalós, R., Benedek, Zs., Czúcz, B., Gálhidy, L., Kovács, B., Standovár, T. \& Tímár, G. (2013): Hazai erdők jövője a klímaváltozás tükrében. - Természet Világa 144: 7-10.

Kenderes, K. (2008): Kelet-közép európai bükkösök természetes faállomány-dinamikája. - Doktori értekezés. Témavezető: Standovár Tibor. Eötvös Loránd Tudományegyetem.

Lihai, W. (1996): Assessment of animal skidding and ground machine skidding under mountain conditions. - J. For. Res. 7: 63-72. doi: https://doi.org/10.1007/BF02843060

Schelhaas, M.-J., Nabuurs, G.-J. \& Schuck, A. (2003): Natural disturbances in the European forests in the 19th and 20th centuries. - Global Change Biol. 9: 1620-1633. doi: https://doi.org/10.1046/ j.1365-2486.2003.00684.x

Standovár, T., Aszalós, R. \& Kenderes, K. (2006): Középhegységi lomberdők természetes bolygatásainak vizsgálata távérzékeléses módszerekkel. - Project Report. OTKA.

Standovár, T., Szmorad, F., Kovács, B., Kelemen, K., Plattner, M., Roth, T. \& Pataki, Zs. (2016): A novel forest state assessment methodology to support conservation and forest management planning. - Community Ecol. 17: 167-177. doi: https://doi.org/10.1556/168.2016.17.2.5

Tanács, E., Orbán, I., Zoltán, L. \& Standovár, T. (2017): A 2014. decemberi jég hatására dőléssel és koronatöréssel érintett erdőállományok azonosítása légifotók objektum-alapú elemzésével. In: Mizsei, E. \& Szepesváry, Cs. (szerk.): XI. Magyar Természetvédelmi Biológiai Konferencia Absztrakt kötet. Magyar Biológiai Társaság, pp. 128-129.

Zoltán, L. (2018): A 2014-es jégtörés és az azt követö kitermelés hatásai a Börzsöny erdeiben. Diplomamunka. Témavezető: Standovár Tibor. Eötvös Loránd Tudományegyetem. 
Zoltán, L. \& Standovár, T. (2017): A 2014-es jégtörés okainak és hatásainak elemzése a Börzsöny erdeiben. - In: Blanka, V. \& Ladányi, Zs. (szerk.): Interdiszciplináris tájkutatás a XXI. században. A VII. Magyar Tájökológiai Konferencia tanulmányai. Szegedi Tudományegyetem Földrajzi és Földtudományi Intézet, pp. 649-656.

\title{
Attributes and effects of salvage logging after the ice break disturbance in the Börzsöny Mts., 2014
}

\author{
László Zoltán and Tibor Standovár \\ Eötvös Loránd University, Department of Plant Systematics, Ecology and Theoretical \\ Biology, H-1117, Budapest, Pázmány Péter sétány 1/C \\ e-mail:zoltan.laci93@gmail.com
}

In the last decades, natural disturbances have caused increasing damages in European forests. In 2014, catastrophic ice damage (the worst in 50 years) occurred in the Börzsöny Mts., Hungary. In our study, we made a quantitative description and comparison of ice disturbance events of the last 20 yrs. in the Börzsöny Mts. We also examined the effects of the 2014's ice disturbance: we resampled 885 sampling points with the same methodology which was used before the ice break. Our results showed that the decrease in canopy closure resulted in increased cover of nitrophilic herbaceous plants and low (below $0.5 \mathrm{~m}$ ) tree regeneration. We also showed that the salvage logging (and the applied techniques) have an impact on the mentioned cover changes. Compared with traditional logging techniques (horse or human powered), logging with machines could generate more severe damage in the saplings, and could contribute to the increase in the cover of nitrophilic herbs. In the Pogány-Rózsás Forest Reserve (which has been unmanaged for some decades) compared with the managed forests, had slightly less serious effects of the ice break.

Keywords: close-to-nature forest management, disturbance indicator herbs, Fagus sylvatica, forest reserve, ice damage, salvage logging, natural disturbances, nitrophilic herbs 